\title{
Atomic Force Microscopy of Biomaterials, Mica, and the Origins of Life
}

\author{
Helen Greenwood Hansma
}

\section{Department of Physics, University of California, Santa Barbara, CA 93106}

Preparing and imaging biomaterials with the Atomic Force Microscope (AFM) or Scanning Probe Microscope (SPM) is, in many ways, an art as well as a science. Some methodological approaches are easily communicated. Other approaches are often nearly subconscious, such as the choice of rinsing a sample with a stream of water directed directly at the sample spot or directed above the sample spot, such that the water flows more gently over the sample spot. Similarly, each AFM tip is unique and changes even during use, as it picks up or loses material. One approach that is sometimes useful for improving tips is to move to an 'unimportant' area of the sample and image at high speed and high force. Operation of the AFM is also a combination of art and science that involves learning general rules for cantilever tuning, imaging forces, speeds and gains and then manipulating these variables to optimize the imaging of the specific sample under the cantilever's probe tip.

Exciting breakthroughs were made in some of our earliest work, such as the time-lapse movie of fibrin polymerization [1] and reproducible imaging of DNA under propanol [2]. Later research included time-lapse movies of DNA [3, 4], other research on DNA [5-7], the extracellular matrix [8,9], and synaptic vesicles [10, 11], analyses of bacterial biofilms $[12,13]$, and pulling on spider silk [14, 15]. AFM methods are presented in [16], and reviews include [17-19]

An unexpected offshoot of biological AFM has been the hypothesis that life might have originated between mica sheets $[20,21]$. The spaces between mica sheets provide many adjacent chambers or "cells" in which pre-cellular life could have developed, in an environment rich in potassium ions and low in entropy. Mica also provides an endless energy source - mechanical energy or Work - that might have been used to form covalent bonds, restructure polymers, and bleb daughter cells off the earliest protocells.

\section{References}

[1] B. Drake, et al., Science, vol. 243, pp. 1586-9, 1989.

[2] H. G. Hansma, et al., Science, vol. 256, pp. 1180-1184, 1992.

[3] M. Bezanilla, et al., Biophys. J., vol. 67, pp. 2454-2459, 1994.

[4] M. Argaman, et al., Nucleic Acids Res., vol. 25, pp. 4379-4384, 1997.

[5] H. G. Hansma and D. E. Laney, Biophys. J., vol. 70, pp. 1933-1939, 1996.

[6] R. Golan, et al., Biochemistry, vol. 38, pp. 14069-14076, 1999.

[7] J. C. Sitko, et al., Biophysical Journal, vol. 84, pp. 419-431, 2003.

[8] C. H. Chen, et al., Biochem., vol. 37, pp. 8262-8267, 1998.

[9] C. H. Chen and H. G. Hansma, J. Struct. Biol., vol. 131, pp. 44-55, 2000.

[10] D. E. Laney, et al., Biophys. J., vol. 72, pp. 806-813, 1997.

[11] R. A. Garcia, et al., J. Neuroscience Res., vol. 52, pp. 350-355, 1998.

[12] I. Auerbach, et al., J. Bacteriol., vol. 182, pp. 3809-3815, 2000.

[13] R. E. Steinberger, et al., Microbial Ecology, vol. 43, pp. 416-423, 2002. 
[14] E. Oroudjev, et al., Proc. Natl. Acad. Sci. USA, vol. 99, pp. 6460-6465, 2002 2002.

[15] N. Becker, et al., Nature Materials, vol. 2, pp. 278-83, 2003.

[16] J. H. Kindt, et al., Methods Cell Biol, vol. 68, pp. 213-29, 2002.

[17] H. G. Hansma and J. Hoh, Annual Review of Biophysics and Biomolecular Structure, vol. 23, pp. 115-139, 1994.

[18] H. G. Hansma, et al., Journal of Structural Biology, vol. 119, pp. 99-108, 1997.

[19] H. G. Hansma, Ann. Rev. Physical Chemistry, vol. 52, pp. 71-92, 2001.

[20] H. G. Hansma, in Probing Mechanics at Nanoscale Dimensions, in Probing Mechanics at Nanoscale Dimensions, edited by N. Tamura, A. Minor, C. Murray, L. Friedman (Mater. Res. Soc. Symp. Proc. Volume 1185, Warrendale, PA, 2009), 1185-II03-15.

[21] H. G. Hansma, Mol. Biol. Cell, vol. 18(suppl), p. Abstract\#1910, 2007.
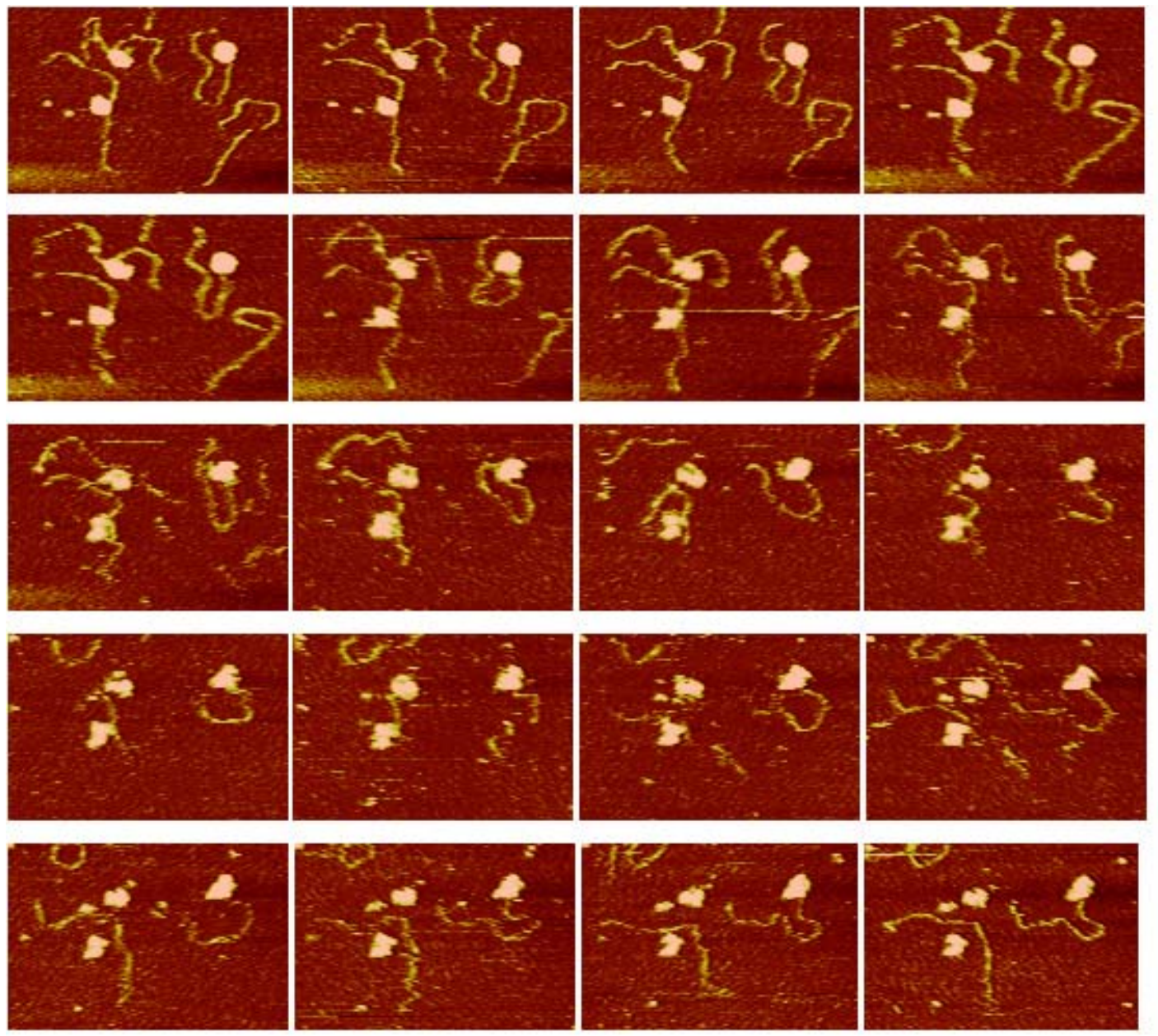

Figure 1. Time-lapse movie of active complexes of DNA with RNA polymerase (RNAP), under fluid in an AFM. Escherichia coli RNAP transcription complexes were prepared with a 1,047-bp DNA template. Consecutive images are at 42-sec intervals. Top row: DNA strands move near the mica surface in $\mathrm{Zn}(\mathrm{II})$ buffer. 2nd thru 4th rows: RNAP [blobs] transcribe and/or detach from DNA strands after NTPs are introduced (probably in a $\mathrm{Zn}$ (II)-free buffer). Bottom row: $\mathrm{Zn}$ (II) buffer is reintroduced, which holds the DNA onto the mica surface. Images are $330 \mathrm{~nm}$ on the $\mathrm{Y}$ axis. 